\title{
Multilocus sequence typing characterizes diversity of Ureaplasma diversum strains, and intra-species variability induces different immune response profiles
}

Yasmin M. F. S. Andrade ${ }^{1,2}$, Manoel N. Santos-Junior' ${ }^{1}$ Izadora S. Rezende ${ }^{3}$, Maysa S. Barbosa ${ }^{3}$, Aline T. Amorim³, Ícaro B. S. Silva ${ }^{2}$, Ellunny C. Queiroz ${ }^{4}$, Bruno L. Bastos ${ }^{4}$, Guilherme B. Campos ${ }^{4}$, Jorge Timenetsky ${ }^{3}$ and

Lucas M. Marques ${ }^{1,3,4^{*}}$ (D)

\begin{abstract}
Background: Ureaplasma diversum is a pathogen found in the genital tract of cattle and associated with genital disorders such as infertility, placentitis, abortion, birth of weak calves, low sperm motility, seminal vesiculitis and epididymitis. There are few studies evaluating the genetic diversity of $U$. diversum strains and their influence on the immune response in cattle. Therefore, to better understand genetic relationships of the pathogenicity of $U$. diversum, a multilocus sequence typing (MLST) scheme was performed to characterize the ATCC 49782 strain and another 40 isolates recovered from different Brazilian states.

Results: Primers were designed for housekeeping genes $\mathrm{ftsH}$, polC, rpL22, rpoB, valS and ureA and for virulence genes, phospholipase D (p/d), triacylglycerol lipase (tg), hemolysin (hlyA), MIB-MIP system (mib,mip), MBA (mba), VsA $(V s A)$ and ribose transporter ( $t A B C)$. PCRs were performed and the targeted gene products were purified and sequenced. Sequence types (STs), and clonal complexes (CCS) were assigned and the phylogenetic relationship was also evaluated. Thus, a total of 19 STs and 4 CCs were studied. Following the molecular analysis, six isolates of U. diversum were selected, inoculated into bovine monocyte/macrophage culture and evaluated for gene expression of the cytokines TNF-a, IL-1, IL-6, IL-10 and IL-17. Differences were detected in the induction of cytokines, especially between isolates 198 and BA78, promoted inflammatory and anti-inflammatory profiles, respectively, and they also differed in virulence factors.
\end{abstract}

Conclusion: It was observed that intra-species variability between isolates of $U$. diversum can induce variations of virulent determinants and, consequently, modulate the expression of the triggered immune response.

Keywords: Mollicutes, Genetic diversity, Sequence type, Clonal complex, Gene expression, Cytokines

\footnotetext{
* Correspondence: Imirandamarques@gmail.com

'Universidade Estadual de Santa Cruz, Brazil, Jorge Amado Highway, Km 16, Salobrinho, Ilheus, Bahia 45662-900, Brazil

${ }^{3}$ Instituto de Ciências Biomedicas, Universidade de Sao Paulo, Brazil, Professor Lineu Prestes Avenue, 2415, Butantã, São Paulo 05508-900, Brazil

Full list of author information is available at the end of the article
}

C C The Author(s). 2020 Open Access This article is licensed under a Creative Commons Attribution 4.0 International License, which permits use, sharing, adaptation, distribution and reproduction in any medium or format, as long as you give appropriate credit to the original author(s) and the source, provide a link to the Creative Commons licence, and indicate if changes were made. The images or other third party material in this article are included in the article's Creative Commons licence, unless indicated otherwise in a credit line to the material. If material is not included in the article's Creative Commons licence and your intended use is not permitted by statutory regulation or exceeds the permitted use, you will need to obtain permission directly from the copyright holder. To view a copy of this licence, visit http://creativecommons.org/licenses/by/4.0/. The Creative Commons Public Domain Dedication waiver (http://creativecommons.org/publicdomain/zero/1.0/) applies to the data made available in this article, unless otherwise stated in a credit line to the data. 


\section{Background}

Ureaplasma diversum, the only ureaplasma found in cattle, was first isolated in 1967 and produces urease and hydrolyzes urea in ammonia, and has no cell wall or mobility structures [1]. It invades epithelial cells of the respiratory and genital tracts from cattle, and therefore, is related to reproductive diseases by interfering with implantation and embryonic development [2]. Disorders such as vulvovaginitis, salpingitis, endometritis, fetal alveolitis, infertility, abortion or birth of weak calves in cows and seminal vesiculitis, epididymitis in bulls, are strongly associated with $U$. diversum [2]. Few studies have reported the mechanisms of $U$. diversum pathogenicity; however, it is known that ammonia, its main metabolite, is toxic to cells and tissues of the host it invades [3]. In addition, bacterial phospholipase production favors prostaglandin synthesis, promoting uterine contractions and abortions [3]. The infection also reduces reproductive potential by inducing inflammatory cytokine secretion by macrophages [3]. Ureplasma diversum has been demonstrated to be able to invade and induce apoptosis in HEp-2 cells, invade sperm leading to loss of semen quality, as well as express molecules that trigger immune response by proinflammatory cytokine production (IL- $1 \alpha$, IL-1 $\beta$, IL- 6 , IL- 8 and TNF- $\alpha$ ), opsonization by antibodies and complement system, and infiltration of neutrophils and macrophages in infected sites [4-6].

Ureaplasma diversum isolates may present distinct patterns of virulence, pathogenicity and gene expression that trigger the immune response [7]. In this context, molecular typing techniques help better understand the diversity in this mollicute. Multilocus sequence typing (MLST) is an advantageous and sensitive technique for assessing genetic variability by comparing sequences from a set of constitutive genes and precisely identifying nucleotide changes, in addition to accommodating information in a database [8]. Thus, the present study aims to observe the diversity of strains isolated in Brazil and to evaluate whether the variability can result in differences in expressing immunological markers, contributing to new perspectives on interventions in preventing and treating diseases caused by $U$. diversum.

\section{Results}

MLST scheme characterized the diversity of strains of $U$. diversum

In this study, seven housekeeping genes of $U$. diversum were selected; however, only six were sequenced successfully and rpL22 gene did not show polymorphisms between the isolates. The size of the amplicons varied between $248 \mathrm{bp}$ and $809 \mathrm{bp}$ (Table 1). NRDB assigned the respective alleles from the identification of variations between the sequences, and the allelic profile formed for each strain defined the STs (Table 2). Hence, the 45 isolates were classified into $19 \mathrm{STs}$, and some STs were grouped into 4 CCs. Six STs were assigned to CC1, 3 STs grouped in CC2 and CC4, 2 STs in CC3 while 5 STs were not grouped in any CC (Table 3).Thus, 26 isolates (57.7\%) were present in different CCs, and 19 isolates $(42.3 \%)$ were not grouped. Therefore, genetic variations were observed among the 45 strains and between farms (Table 3). Figure 1 outlines these different clonal groups with their respective STs, as well as unique STs.

\section{Phylogeny analyses}

The tree constructed from concatenated sequences of the six housekeeping genes revealed many branches. A variable number of isolates are related in the different branches of the tree, while others are not, which indicates molecular diversity of the strains of $U$. diversum, agreeing with the data obtained by MLST (Fig. 2).

\section{Virulence factors of $U$. diversum}

Detection of the virulence genes was performed for the 45 strains of this study. The size of the amplicons varied between $255 \mathrm{bp}$ and $924 \mathrm{bp}$ (Table 1). Phospholipase D (pld) was identified in $18(40 \%)$ isolates, triacylglycerol lipase $(\operatorname{tgl})$ in $37(82.2 \%)$, hemolysin $(h l y A)$ and MIB (mib) found in 35 (77.7\%) samples, MIP (mip) in 32 (71.1\%). The genes $m b a$ and $V s A$ were detected in 33 $(73.3 \%)$ isolates and the ribose $\mathrm{ABC}$ transporter $(t A B C)$ in 41 (91.1\%) ureaplasmas.

\section{$U$. diversum strains have different profiles of pathogenicity and inflammatory response}

Results of cytokine gene expression TNF- $\alpha$, IL-1, IL-6, IL-10 and IL-17 after infection of monocytes / macrophages by different strains $U$. diversum are shown in Fig. 3. The studied isolates presented different clonal groups and singleton STs: BA78 (CC1), GOTA (CC2), 198 (CC3), ATCC 49782 (CC4), 805 (ST13) and S8 (ST18). For TNF- $\alpha$ and IL-6, it was observed that strain 198 significantly induced the expression of these genes compared to the negative control, and there were differences between the control groups of these cytokines $(P<0.05)$. A statistically significant difference was identified between 198 / BA78 strains and BA78 / LPS expression in IL-1 cytokine expression. For IL-17, there were statistically significant differences between strains BA78 / 805 and 805 / GOTA. And IL-10 gene expression was significantly induced by BA78 and GOTA strains compared to the negative control. Thus, herein, the studied $U$. diversum, showed different cytokine profiles. The isolate 198 induced significant expression of proinflammatory cytokines (TNF- $\alpha$, IL-1 and IL-6), whereas BA78 and GOTA, despite inducing IL-17, led to a significant increase in IL-10. It was observed that, mainly, 
Table 1 Genes selected for MLST scheme and virulence analysis, with their respective primers designed from access to categorized genes of $U$. diversum ATCC 49782. F indicates forward and $R$ indicates reverse

\begin{tabular}{|c|c|c|c|c|}
\hline Gene & Primer & Primer Sequence $5^{\prime}-3^{\prime}$ & Gene length & Amplicon \\
\hline \multicolumn{5}{|c|}{ MLST scheme } \\
\hline \multirow[t]{2}{*}{$\mathrm{ftsH}$} & $\mathrm{ftsH}-\mathrm{F}$ & CAGTGCGTGATAACAAAACTG & 1533 bp & $753 \mathrm{bp}$ \\
\hline & $\mathrm{ftsH}-\mathrm{R}$ & CAACTACATCAGCTTCTTCAGC & & \\
\hline \multirow[t]{2}{*}{ polc } & polC - F & ACGGATCTCAGGTTTATCTCAT & $4305 \mathrm{bp}$ & $653 \mathrm{bp}$ \\
\hline & polC - R & CAGGAAGCATTGTAAAAGGTG & & \\
\hline \multirow[t]{2}{*}{$r p L 22$} & rpL22 - F & CTCAGCAGTTGCTAATGTAACT & 972 bp & $809 \mathrm{bp}$ \\
\hline & rpL22 - R & AGTATTGGAACCCACTTGG & & \\
\hline \multirow[t]{2}{*}{ rpoB } & rpoB - F & AGCCGTATGAACATTGGAC & $4281 \mathrm{bp}$ & $718 \mathrm{bp}$ \\
\hline & rpoB - R & ACTTGAATGATTCAGGCATTCC & & \\
\hline \multirow[t]{2}{*}{ ureA } & ureA - F & CGACCTTGCTCGTAGACGT & $306 \mathrm{bp}$ & $248 \mathrm{bp}$ \\
\hline & ureA - R & AGATAGGTTCGTGAATTGACAC & & \\
\hline \multirow[t]{2}{*}{ vals } & valS - F & TGCTCCTTGTATTAGTGAAGAC & $2616 \mathrm{bp}$ & $468 \mathrm{bp}$ \\
\hline & valS - R & GCTGGGGCTITAGATGTAAA & & \\
\hline \multicolumn{5}{|c|}{ Virulence genes } \\
\hline \multirow[t]{2}{*}{ pld } & pld - F & CCAACTGAAGAGTTGATTGTAGC & $615 \mathrm{bp}$ & $396 \mathrm{bp}$ \\
\hline & pld - R & GGTTTCAACAACCTGTCTTGCG & & \\
\hline \multirow[t]{2}{*}{$\operatorname{tgl}$} & $\operatorname{tgl}-\mathrm{F}$ & ATTGCTTGTATGCTTGCGGAAG & 873 bp & $546 \mathrm{bp}$ \\
\hline & $\operatorname{tgl}-\mathrm{R}$ & ATCACCCTCTGATTCTTCAACT & & \\
\hline \multirow[t]{2}{*}{ hlyA } & hlyA - F & GGAGTTGTTCGTTATGTTGGA & $1389 \mathrm{bp}$ & $463 \mathrm{bp}$ \\
\hline & hlyA - R & CAACAAGCCGACTAAATCCAGT & & \\
\hline \multirow[t]{2}{*}{ mib } & mib - F & GATACACCGATTGAACCTCCA & 2484 bp & $924 \mathrm{bp}$ \\
\hline & mib - R & TCAACCAGGATAACTTCCTTGA & & \\
\hline \multirow[t]{2}{*}{ mip } & mip - F & ACGAATTTGAAGGTAAGGTAGC & $2400 \mathrm{bp}$ & $539 \mathrm{bp}$ \\
\hline & mip - R & TCAACTTGCTTGTTGACCAGG & & \\
\hline \multirow[t]{2}{*}{$m b a$} & $m b a-F$ & GTTGGTGCTATTATGGCAGGG & 1398 bp & 704 bp \\
\hline & $m b a-R$ & CCATTGTTGGACTAGGAGTT & & \\
\hline \multirow[t]{2}{*}{ VsA } & VsA - F & AACCTAATCTTGGTTCTGACC & 1227 bp & 255 bp \\
\hline & VsA - R & CTTCGCTTCCTGAACCTTCCAT & & \\
\hline \multirow[t]{2}{*}{$\operatorname{tABC}$} & $t A B C-F$ & CGCTTATTTGCTGCGGTATTA & $936 \mathrm{bp}$ & $683 \mathrm{bp}$ \\
\hline & $t A B C-R$ & CAAGTGCTAAGAATCCAGCTCC & & \\
\hline
\end{tabular}

isolates 198 and BA78 elicited differentiation of the studied immune responses. The heat map separated the cytokine expression profile into three distinct clusters (cluster 1: 198 and LPS; cluster 2: 805, BA78 and NC; cluster 3: ATCC, GOTA and S8) and, together with the qPCR data, shows different expression patterns induced by different strains of $U$. diversum (Fig. 4). The relationship between gene expression of cytokines and virulence genes present in the six selected strains (Fig. 5) was also observed and, in a more summarized way, Table 4 associates the origin of the isolates with pathogenicity and inflammatory modulation (comparing the expression data with the control group), showing that ureaplasmas induce antagonistic profiles of the immune response. Note that the greater the number of virulence genes found, the greater the anti-inflammatory induction (Fig. 6). Thus, while strain 198 (vulvovaginitis origin) did not show any of the virulence genes and increased expression of pro-inflammatory cytokines, strain BA78 (vulvovaginitis origin) induced an anti-inflammatory profile and exhibited most of the evaluated virulence genes.

\section{Discussion}

The diversity of strains of $U$. diversum was analyzed through an MLST technique. Based on previous studies, in which genes were chosen for their chromosomal location and diversity of sequences found, [9] and the Manatee database (ATCC strain 49,782), a set of housekeeping genes was selected: $f t s H, r p L 22, v a l S, t h r S, r p o B, p o l C$ and 
Table 2 Allelic profile and sequence types (ST) of the 45 strains of $U$. diversum

\begin{tabular}{lllllllll}
\hline Strains & \multicolumn{2}{l}{ Allelic profile } & & & & ST \\
\cline { 2 - 7 } & ftsH & polC & rpL22 & rpoB & ureA & vals & \\
\hline $5 T$ & 1 & 1 & 1 & 1 & 1 & 1
\end{tabular}

Table 3 Strains of $U$. diversum isolated from different Brazilian states, São Paulo (SP), Mato Grosso do Sul (MT), Minas Gerais (MG) and Bahia (BA) from 1999 to 2005 and their respective sequence types (ST) and clonal complexes (CC)

\begin{tabular}{|c|c|c|c|c|}
\hline Farm & State & Strain & ST & CC \\
\hline \multirow[t]{2}{*}{1} & $\mathrm{SP}$ & A203 & ST15 & $\mathrm{CC} 4$ \\
\hline & $\mathrm{SP}$ & 59 & ST6 & $\mathrm{CC} 1$ \\
\hline \multirow[t]{7}{*}{2} & SP & GOTA & ST17 & $\mathrm{CC} 2$ \\
\hline & $\mathrm{SP}$ & 93 & ST8 & $\mathrm{CC} 2$ \\
\hline & $\mathrm{SP}$ & 94 & ST8 & $\mathrm{CC} 2$ \\
\hline & SP & 95 & ST8 & $\mathrm{CC} 2$ \\
\hline & $\mathrm{SP}$ & 98 & ST9 & $\mathrm{CC} 2$ \\
\hline & $\mathrm{SP}$ & 100 & ST9 & $\mathrm{CC} 2$ \\
\hline & $\mathrm{SP}$ & 102 & ST9 & $\mathrm{CC} 2$ \\
\hline \multirow[t]{3}{*}{3} & $\mathrm{SP}$ & 72 & ST7 & SINGLETON \\
\hline & $\mathrm{SP}$ & 73 & ST7 & SINGLETON \\
\hline & $\mathrm{SP}$ & 84 & ST7 & SINGLETON \\
\hline \multirow[t]{5}{*}{4} & $\mathrm{SP}$ & $5 \mathrm{~T}$ & ST1 & SINGLETON \\
\hline & $\mathrm{SP}$ & $7 \mathrm{~T}$ & ST1 & SINGLETON \\
\hline & SP & $10 \mathrm{~T}$ & ST1 & SINGLETON \\
\hline & $\mathrm{SP}$ & $13 \mathrm{~T}$ & ST1 & SINGLETON \\
\hline & $\mathrm{SP}$ & $16 \mathrm{~T}$ & ST1 & SINGLETON \\
\hline \multirow[t]{2}{*}{5} & $\mathrm{SP}$ & S6 & ST18 & SINGLETON \\
\hline & $\mathrm{SP}$ & S8 & ST18 & SINGLETON \\
\hline \multirow[t]{2}{*}{6} & MT & 805 & ST13 & SINGLETON \\
\hline & MT & 9653 & ST13 & SINGLETON \\
\hline 7 & MG & Ud18 & ST19 & CC4 \\
\hline \multirow[t]{8}{*}{8} & BA & 34 & ST2 & $\mathrm{CC} 1$ \\
\hline & BA & 35 & ST3 & $\mathrm{CC} 1$ \\
\hline & BA & 37 & ST3 & $\mathrm{CC} 1$ \\
\hline & BA & 78 & ST7 & SINGLETON \\
\hline & BA & 83 & ST7 & SINGLETON \\
\hline & BA & 84.2 & ST7 & SINGLETON \\
\hline & BA & 89 & ST7 & SINGLETON \\
\hline & BA & BA78 & ST16 & $\mathrm{CC} 1$ \\
\hline \multirow[t]{6}{*}{9} & BA & 47 & ST3 & CC1 \\
\hline & BA & 51 & ST3 & $\mathrm{CC} 1$ \\
\hline & BA & 52 & ST4 & $\mathrm{CC} 1$ \\
\hline & BA & 54 & ST5 & $\mathrm{CC} 1$ \\
\hline & BA & 55 & ST5 & $\mathrm{CC} 1$ \\
\hline & $\mathrm{BA}$ & 56 & ST6 & $\mathrm{CC} 1$ \\
\hline \multirow[t]{3}{*}{10} & BA & 234 & ST12 & SINGLETON \\
\hline & BA & 239 & ST12 & SINGLETON \\
\hline & BA & 249 & ST12 & SINGLETON \\
\hline \multirow[t]{5}{*}{11} & BA & 111 & ST10 & $\mathrm{CC} 3$ \\
\hline & BA & 133 & ST10 & $\mathrm{CC} 3$ \\
\hline & BA & 148 & ST10 & $\mathrm{CC} 3$ \\
\hline & BA & 174 & ST11 & $\mathrm{CC} 3$ \\
\hline & BA & 198 & ST11 & $\mathrm{CC} 3$ \\
\hline
\end{tabular}




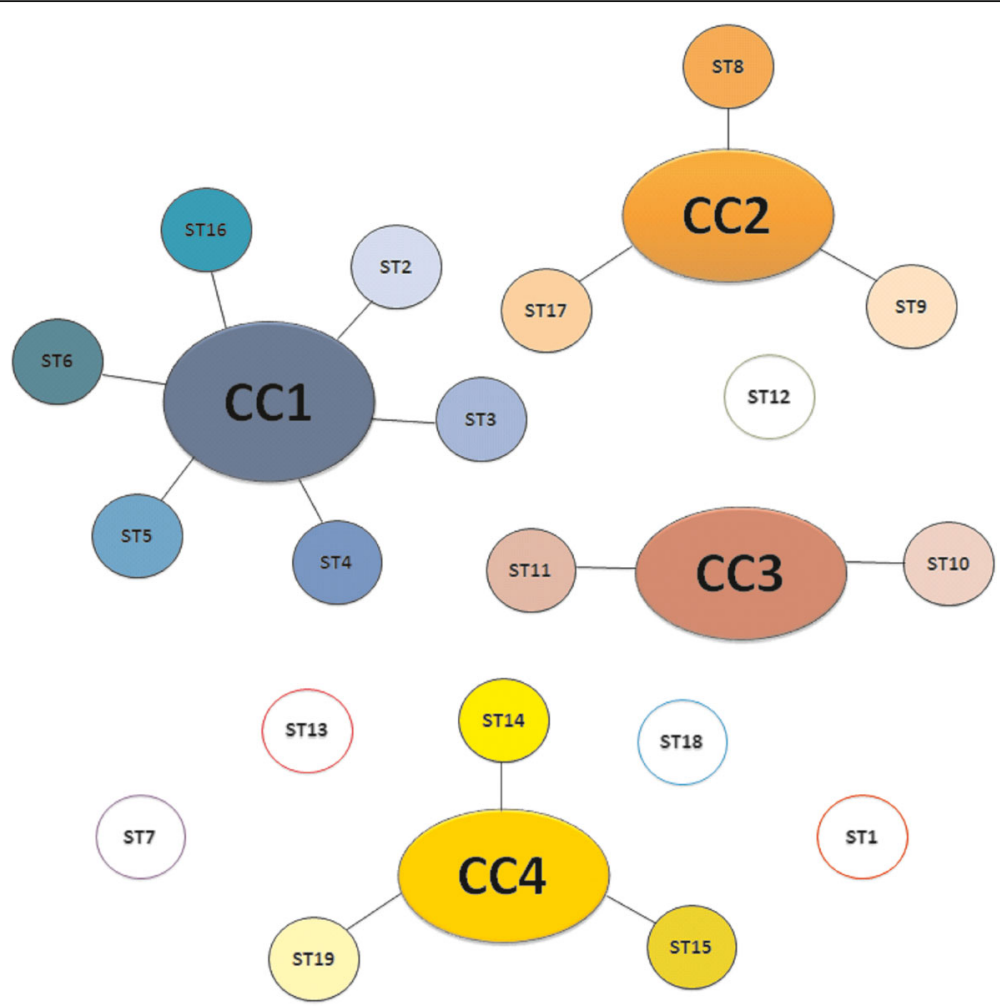

Fig. 1 Schematic model MLST. Each large circle represents a CC linked with respective STs, in smaller circles. Circles not linked to any CC are singleton STs

ureA. However, thrS was not properly sequenced. The fts $H$ gene encodes essential proteases [10], rpL22 encodes ribosomal proteins [11], polC encodes the unique DNA polymerase found in mycoplasmas, DNA polymerase III [12], rроB encodes $\beta$-subunit of RNA polymerase [13], valS catalyzes amino acid activation and tRNA transfers [14] and the ureA gene encodes urease that catalyzes urea in ammonia [15]. Out of 6 genes evaluated, $r p L 22$ did not present polymorphisms between the strains evaluated, which does not reduce the sensitivity and efficiency of the method and shows the possibility of executing the MLST scheme with five housekeeping genes for molecular typing of $U$. diversum, as was done for $M$. agalactiae [16], $M$. bovis [17], for example. In addition, it is interesting to develop an MLST scheme combining housekeeping and virulence genes (expanded multilocus sequence typing eMLST) to improve the high resolution of the technique [18] and allow the identification of important molecular markers for the differentiation of pathogenic and nonpathogenic strains.

The MLST scheme has already been used for mycoplasmas: M. arginini [19], M. pneumoniae [20], M. hyorhinis [21], M. agalactiae [22], M. hyopneumoniae [23], M. mycoides [24], M. bovis [25]. In 2013, MLST technique was developed for species of ureaplasmas that infect humans [9]. The present study is the first report of MLST applied to the diversity analysis of $U$. diversum and identified 19 STs. Different genetic sequences are classified as distinct alleles. The set of the alleles form the allelic profile and defines the ST, assigning a random number [26]. In this study ST7 was the most frequent; however, it was not grouped in CC. From the ureaplasma studied, $42.3 \%$ were singleton STs. These STs did not share, at least, three alleles with other STs, and therefore are considered the most genetically diverse isolates [26]. The variety of STs found indicates that there was a gene recombination [27].

Clonal complexes are formed, at least, from two different STs that must share, at least, three alleles with each other [19]. Thus, we detected four CCs: CC1, CC2, CC3, and $\mathrm{CC} 4$, indicating a genetic variation among isolates. These data suggest that herd and animal management may influence ureaplasma variability due to environmental pressures [26]. In addition, the absence of some DNA repair mechanisms helps preserve the genetic diversity of mollicutes [28]. Phylogenetic data also expressed this molecular diversity observed among strains of $U$. diversum. Some isolates were clustered while others were not, according to the data obtained by MLST. Isolates from the same clade are equivalent to isolates belonging to the same clone or the same ST; in addition, nongrouped strains also represent ST singletons (Fig. 2). 


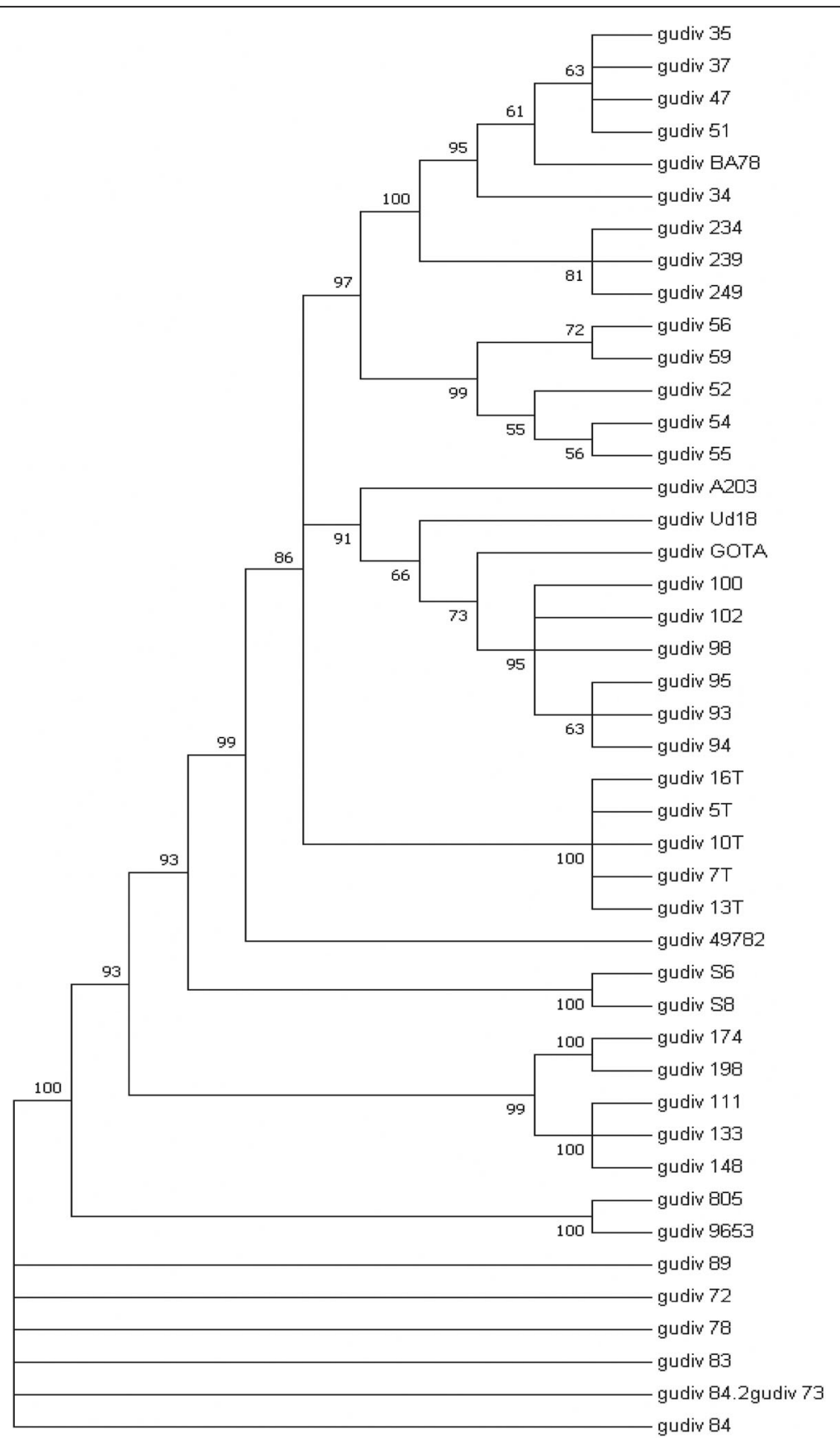

Fig. 2 Phylogenetic tree with 45 strains of U. diversum, constructed from concatenated sequences of 6 housekeeping genes (ftsH, rpL22, valS, rpoB, po/C and ureA) using neighbor-joining method 1000 bootstraps

Virulence factors were also analyzed for the studied $U$. diversum. Based on the ATCC strain sequencing [2], primers were designed for different genes. We observed that the phospholipase D gene ( $p l d$ ) was found in $40 \%$ of the isolates. This enzyme alters the synthesis of prostaglandins $\mathrm{E}_{2}$ and $\mathrm{F}_{2 \mathrm{a}}$ by endometrial cells, rendering pregnancy difficult [3]. Another enzyme from the lipase family, triacylglycerol lipase, was identified in $82.2 \%$ of the isolates. These enzymes are excreted and damage host tissues [29]. The hemolysin gene, detected in $77.7 \%$ of the isolates, causes erythrocyte hemolysis and has $63.1 \%$ identity with the hemolysin protein sequence found in human ureaplasmas [2]. The MIB-MIP system has been described recently; MIB is a protein that binds strongly to IgG, whereas MIP cleaves IgG, contributing to immune system evasion [30]. We reported that $77.7 \%$ of the isolates had mib, and $71.1 \%$ had mip. The surface molecules were also observed; $m b a$ and $V s A$ were 

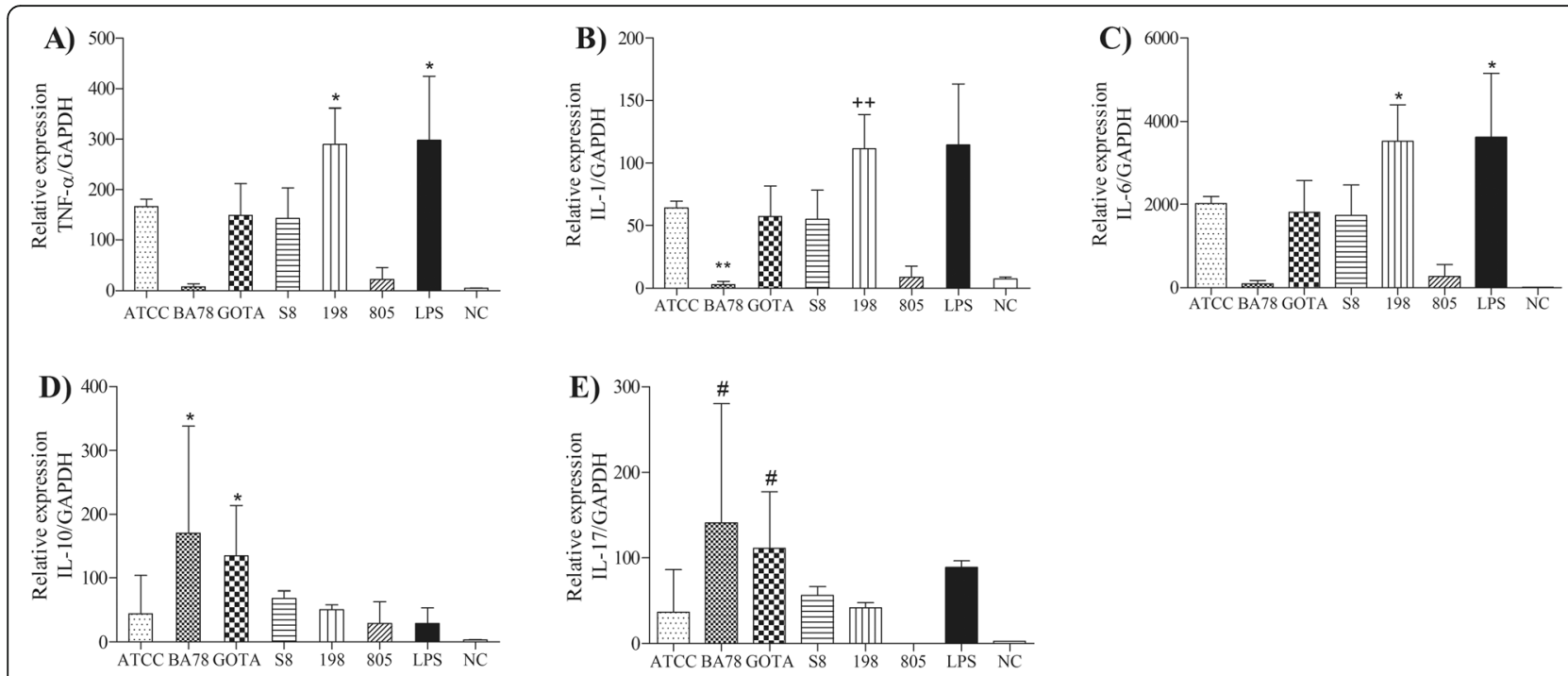

Fig. 3 Gene expression of cytokines in bovine monocytes/macrophages infected by 6 strains of U. diversum representing different clones and singleton STs: BA78 (CC1), GOTA (CC2), 198 (CC3), ATCC 49782 (CC4), 805 (ST13) and S8 (ST18). a TNF expression; b IL-1 expression; c IL-6 expression; d IL-17 expression; e IL-10 expression. Groups were compared using the Kruskal-Wallis non-parametric test followed by the Dunn post-test, statistical significance $P<.05$. PBS was used as negative control (NC) and LPS was used as positive control. *Difference with the group NC; ${ }^{* *}$ difference with the group LPS; ++ difference with the group BA78; \# difference with the group 805

detected in $73.3 \%$ of the isolates. MBA are antibody targets, stimulate monocytes / macrophages and have cytolytic activity, whereas VsA is critical for bacterial survival due to antigenic variations [31]. A ribose transporter gene $(t A B C)$ was identified in $91.1 \%$ of ureaplasma. These sugars are captured by $U$. diversum and are incorporated to form a polysaccharide capsule [2].

To evaluate the implication of the different clones found under the cytokine gene expression patterns, the culture of bovine monocytes / macrophages was infected

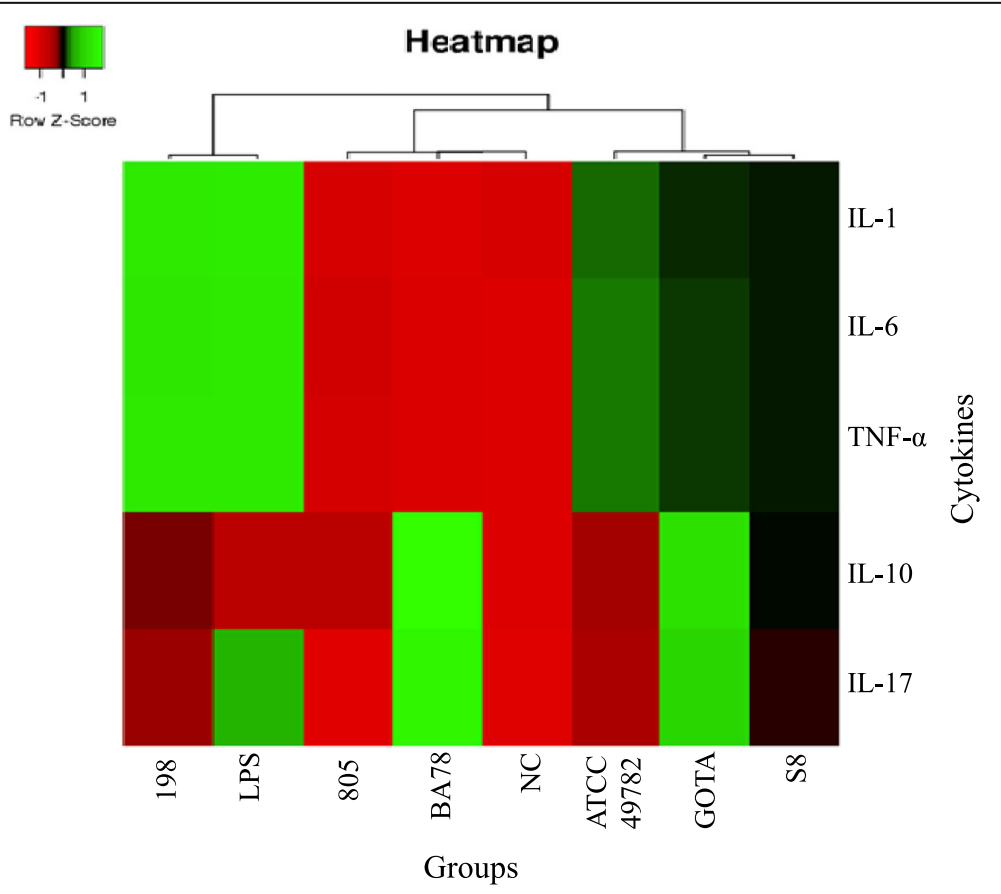

Fig. 4 Heatmapper platform formed three clusters according to expression pattern of cytokines TNF-a, IL-1, IL-6, IL-10 and IL-17 in culture of bovine monocytes / macrophages infected by six strains of U. diversum: BA78, GOTA, 198, ATCC 49782, 805 and S8, using LPS as positive control and PBS as negative control (NC). Red indicates low expression, and green, high expression of cytokines 

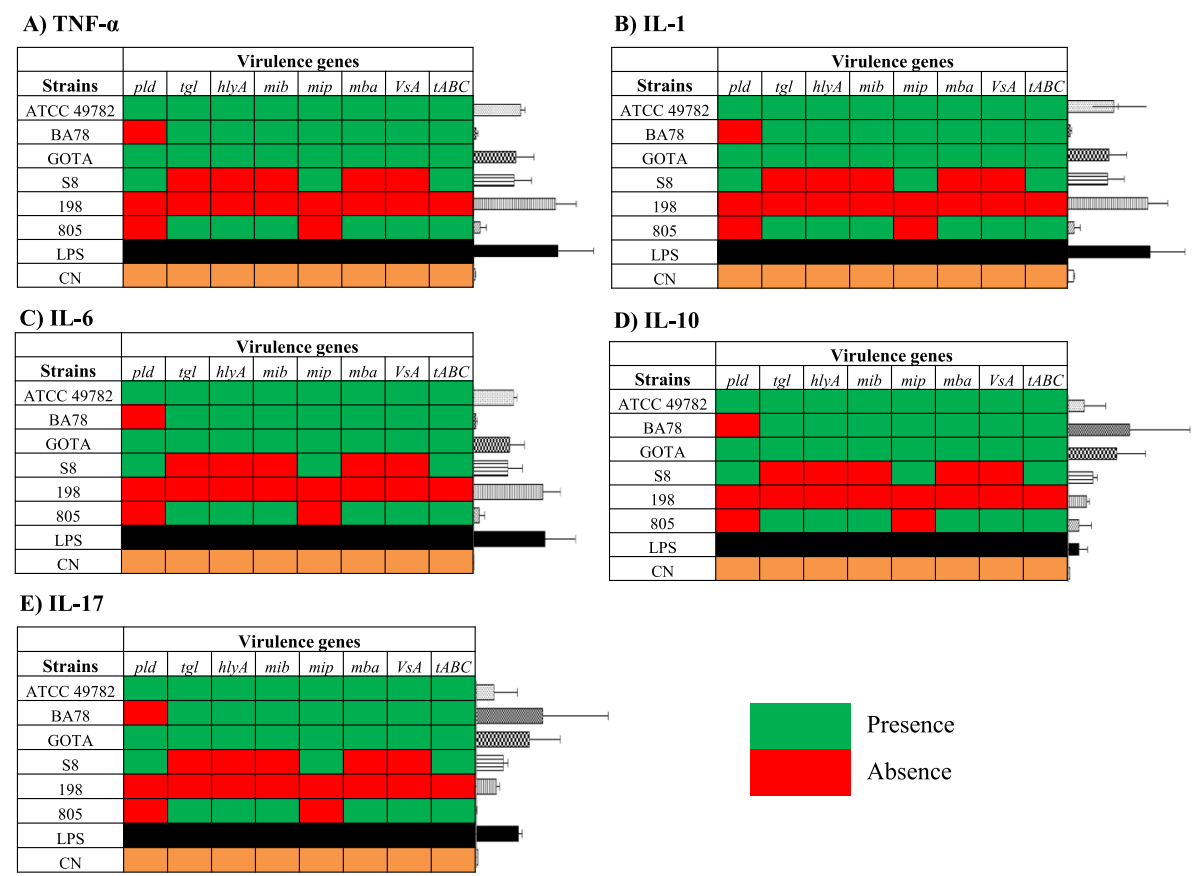

Fig. 5 Relation between virulence genes phospholipase D (pld), triacylglycerol lipase (tgh), hemolysin (hlyA), mib, mip, mba, VsA and ribose transporter $(t A B C)$ with gene expression of cytokines in culture of bovine monocytes / macrophages infected by six strains of $U$. diversum, BA78, GOTA, 198, ATCC 4978, 805 and S8. a) TNF expression; b) IL-1 expression; c) IL-6 expression; d) IL-10 expression; e) IL-17 expression. Green indicates presence of virulence genes, and red indicates a lack of these genes

with six different strains of $U$. diversum (one strain from each CC and two singleton STs) previously selected. We observed that strain 198 significantly increased the expression of the pro-inflammatory cytokines TNF- $\alpha$ and IL-6 compared to the control, as well as induced the expression of IL1 compared to strain BA78. Cytokine IL-17 was induced by strains BA78 and GOTA, in relation to isolate 805. Therefore, these data show different patterns in inducing proinflammatory cytokines by different strains of $U$. diversum. Other literature data also demonstrate cytokine induction by different strains of a microorganism, such as a study that showed differences in the levels of TNF- $\alpha$, IL- 6 and IL-17 induced by different strains of $E$. coli in bovine breast tissue [7] or increased TNF- $\alpha$ expression in bovine PBMC infected with $M$. bovis, as well as IL-6, IL-10 and TNF- $\alpha$ expression induced by culture supernatant of this bacterium [32]. Regarding anti-inflammatory cytokine expression, our results show the induction of IL-10 by BA78 and GOTA strains compared to untreated cells $(P<0.05)$. In this context, it was observed that bovine monocytes infected with $M$. bovis considerably increase the secretion of IL-10 by negatively regulating pro-inflammatory cytokines [33]. Note that BA78 and GOTA strains induced the cytokine expression of an antagonistic nature; therefore, IL-17 expression did not prevent an anti-inflammatory modulation. This cytokine produced by Th17 cells recruits neutrophils; however, it has been reported that IL-17 does not increase the survival of bovine neutrophils after infection with $M$. bovis [34] and the need for synergy of IL-17 with other cytokines has been proposed for improving its function [35].

Table 4 Description of the origin of five strains of $U$. diversum, the molecular groups to which they belong, the virulence genes identified and the inflammatory modulation, comparing the gene expression data with the negative control (NC). $\uparrow$ : increased gene expression

\begin{tabular}{|c|c|c|c|c|c|c|c|c|c|c|c|}
\hline \multirow{2}{*}{$\begin{array}{l}\text { Strains } \\
198\end{array}$} & \multirow{2}{*}{$\begin{array}{l}\text { Source } \\
\text { Vulvovaginitis }\end{array}$} & \multirow{2}{*}{$\begin{array}{l}\text { MLST } \\
\text { CC3 }\end{array}$} & \multicolumn{8}{|c|}{ Virulence gene found } & \multirow{3}{*}{$\begin{array}{l}\begin{array}{l}\text { Modulation } \\
\text { (infected x NC) }\end{array} \\
\uparrow T N F-a, \text { IL-6 } \\
\text { None modulation }\end{array}$} \\
\hline & & & \multicolumn{8}{|c|}{ Absence of evaluated genes } & \\
\hline S8 & Semen & ST18 & pld & & $\operatorname{mip}$ & & & $t A B C$ & & & \\
\hline 805 & Vulvovaginitis & ST13 & $\operatorname{tgl}$ & hlyA & mib & $m b a$ & & VSA & $t A B C$ & & None modulation \\
\hline BA78 & Vulvovaginitis & $\mathrm{CC} 1$ & $\operatorname{tgl}$ & hlyA & mib & $\operatorname{mip}$ & $m b a$ & VSA & $t A B C$ & & $\uparrow \mid L-10$ \\
\hline GOTA & Vulvovaginitis & CC2 & pld & $\operatorname{tgl}$ & hlyA & mib & mip & $m b a$ & VSA & $t A B C$ & $\uparrow I L-10$ \\
\hline
\end{tabular}




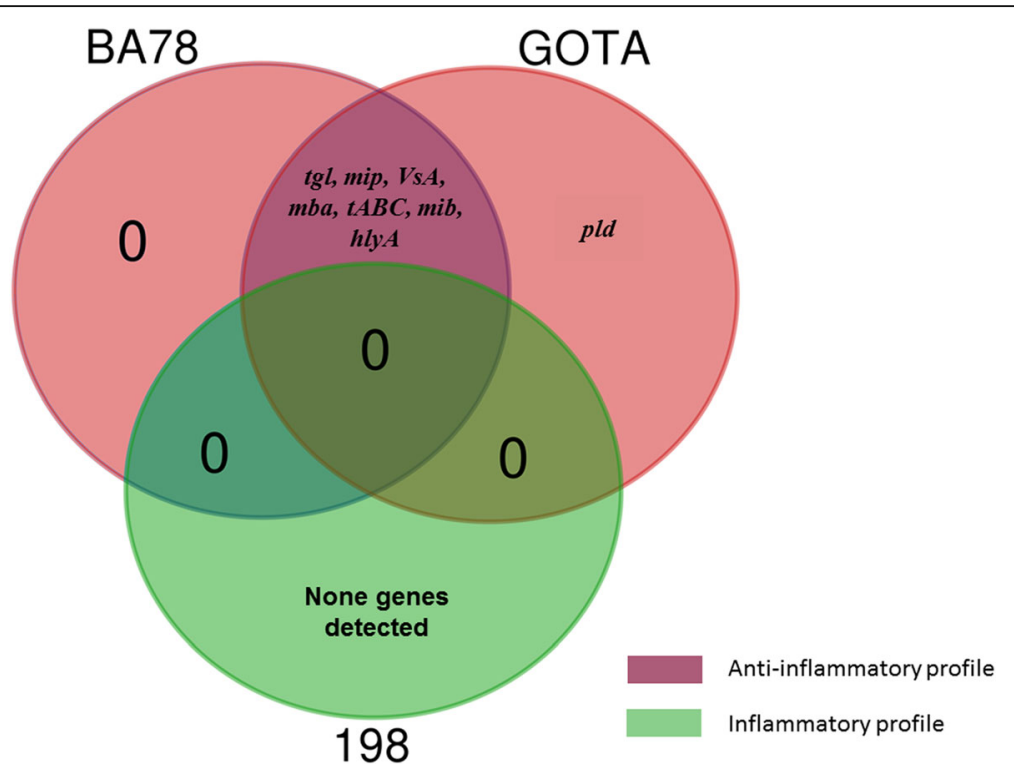

Fig. 6 Venn diagram shows virulence genes related to the immune response profile between strains 198, BA78 and GOTA. We observed that the genes shared by BA78 and GOTA induced an anti-inflammatory profile (purple), while strain 198 did not present any gene and induced expression of pro-inflammatory cytokines (green)

Regarding data of the genic expression to virulence of the strains, it was observed that 198 induced an inflammatory profile, but did not exhibit any virulence gene, whereas BA78 induced an anti-inflammatory profile and exhibited all the genes, except for $p l d$. Inflammation results from the recognition of lipid-associated membrane proteins (LAMPS) through TLRs 2 and 4 that activate the MyD88 and NF-KBsignaling pathway [36, 37]. However, mycoplasma infections are not necessarily related to strong inflammatory responses, because LAMPS can suppress inflammation by inducing IL10 production [33]. In addition, altered surface proteins, such as VsA and MBA, make it difficult to recognize bacteria through the immune cell $[31,38]$. Thus, it is suggested that the BA78 strain used its virulence factors to evade immunity and promote its survival [33], whereas strain 198 may contain other lipoproteins (not evaluated in this study) that were recognized and induced the expression of pro-inflammatory cytokines. Further studies should be conducted to better understand the role of virulence genes in $U$. diversum and their relation with the immune response.

\section{Conclusion}

The genetic variability between strains of $U$. diversum is poorly understood in cattle. Our findings contributed to the understanding of $U$. diversum variability using MLST, a tool that showed intraspecies diversity of the 45 isolates evaluated, assigning them different STs and 4 CCs. The results of gene expression demonstrated differences in the immune response against different strains, mainly between strains 198 and BA78 that modulate inflammatory and anti-inflammatory profiles, respectively. The isolates also exhibited differences in virulence factors. Thus, this study demonstrated the existence of different clones with a consequent variation in virulent determinants that may be associated with gene expression, and these different patterns can impact the pathogenicity of ureplasmas, which could be important to consider in future studies.

\section{Methods}

\section{Cultures of $U$. diversum}

The strain of $U$. diversum ATCC 49782 and 44 field isolates were supplied by the Mycoplasma Laboratory of the Biomedical Sciences Institute, University of São Paulo. Some strains were isolated from cows with granulomatous vulvovaginitis, and others were isolated from the semen of healthy bulls. The bacteria were obtained from the following four states: 19 isolates in São Paulo (farms 1, 2, 3, 4 and 5), 2 isolates from Mato Grosso do Sul (farm 6), 1 isolate from Minas Gerais (farm 7) and 22 isolates from Bahia (farms 8, 9, 10, 11) (Figure S1 in Supplementary file). All microorganisms were cultured in $5 \mathrm{~mL}$ of $\mathrm{UB}$ broth at $37^{\circ} \mathrm{C}$ for 2 days [2]. After growth, the cultures were stored at $-80^{\circ} \mathrm{C}$ for the study. The isolates were first submitted to genetic analysis and, after the genetic groups were defined, and representative profiles of each group were evaluated for pathogenicity.

\section{DNA extraction}

DNA extraction was performed using the Nucleospin DNAtissue commercial kit (Macherey-Nagel, Düren, Germany, 2016), following the manufacturer's recommendations. 


\section{Primers design for MLST and virulence genes}

Based on descriptions from the literature, seven housekeeping genes were selected for the MLST scheme ftsH, rpL22, valS, thrS, rpoB, polC [9] and the ureA gene [2] - while other genes were selected for virulence analysis - phospholipase D (pld) (gudiv_472), triacylglycerol lipase (tgl) (gudiv_748), hemolysin (hlyA) (gudiv_91), MIB-MIP system (mib,mip) (gudiv_161/gudiv_162), surface molecules, such as multiple banded antigens (mba) (gudiv_653), and variable surface antigen lipoprotein (VsA) (gudiv_179) and ribose ABC transporter $(t A B C)$ (gudiv_307) [2]. After selection of loci for MLST and virulence factors, primers were designed. Through the Manatee database (https://manatee.igs.umaryland. edu) it was possible to access the categorized genes of $U$. diversum, strain ATCC 49782. Genomic sequences of interest were obtained and possible primer sequences were chosen at random and their analyses were started through the sites https://www.idtdna.com/calc/analyzer and https://www.bioinformatics.org/sms/rev_comp.html. After checking important parameters for constructing primers (size, GC content, melting temperature and annealing, formation of secondary structures), the similarity performed by BLAST was validated (https://blast. ncbi.nlm.nih.gov/Blast.cgi) to confirm the specificity of the primers for $U$. diversum. Forward and reverse primers for each of the selected genes (housekeeping and virulence) are described in Table 1.

\section{Polymerase chain reaction and electrophoresis}

Amplifications were performed with a total volume of $25 \mu \mathrm{L}$, with $1 \mu \mathrm{L}$ of DNA, 10x PCR buffer $(10 \mathrm{mM}$ Tris$\mathrm{HCl}, \mathrm{pH} 9.0,50 \mathrm{mM} \mathrm{KCl}), 1.5 \mathrm{mM} \mathrm{MgCl}_{2} ; 200 \mu \mathrm{M}$ $\mathrm{dNTP}, 50 \mathrm{pmol}$ of each primer and $1.5 \mathrm{U}$ of Taq DNA polymerase (Invitrogen ${ }^{\circ}$, Brazil). The reactions for $f t s H$, polC, rpL22, urea, valS and all virulence genes occurred with initial denaturation of $94{ }^{\circ} \mathrm{C}$ for $5 \mathrm{~min}$ followed by 35 thermal cycles each consisting of $94{ }^{\circ} \mathrm{C}$ for $30 \mathrm{~s}, 54^{\circ} \mathrm{C}$ for $30 \mathrm{~s}$ and $72{ }^{\circ} \mathrm{C}$ for $1 \mathrm{~min}$, concluding with a final extension at $72{ }^{\circ} \mathrm{C}$ for $5 \mathrm{~min}$. While for the $r p o B$ and thrS genes, there was initial denaturation of $94^{\circ} \mathrm{C}$ for $5 \mathrm{~min}$, followed by 35 thermal cycles each consisting of $94{ }^{\circ} \mathrm{C}$ for $30 \mathrm{~s}, 50^{\circ} \mathrm{C}$ for $30 \mathrm{~s}$ and $72^{\circ} \mathrm{C}$ for $1 \mathrm{~min}$, concluding with a final extension of $72^{\circ} \mathrm{C}$ for $5 \mathrm{~min}$. The targeted products were analyzed by $2 \%$ agarose gel electrophoresis, stained with $2.5 \mu \mathrm{L}$ ethidium bromide $(10 \mathrm{mg} / \mathrm{mL})$, visualized and photographed under UV light. A marker was used as standard to evaluate the size of amplified fragments - 100 bp DNA Ladder (Invitrogen ${ }^{\circ}$, Brazil).

\section{PCR product purification and sequencing for MLST technique}

After electrophoresis, the total volume of the remaining PCR reaction was precipitated with $500 \mu \mathrm{L}$ of $65 \%$ isopropanol, followed by centrifugation at 19,000 xg for 5 min, washing with $250 \mu \mathrm{L}$ of $70 \%$ alcohol and further centrifugation at 19,000 $\mathrm{xg}$ for $5 \mathrm{~min}$. The tubes were inverted for $1 \mathrm{~h}$ to dry at room temperature, then resuspended with $20 \mu \mathrm{L}$ ultrapure water and the primers diluted to $5 \mathrm{pmol}$. Sanger sequencing reactions were performed at the Biomedical Sciences Institute, Federal University of Sao Paulo according to the protocol for the MegaBACE 1000, using the DYEnamic ET Dye Terminator Kit (with Thermo Sequenase $^{\text {mi }}$ II DNA Polymerase) code US81090. The sequences obtained were analyzed by Sequence Analyzer software using the Cimarron Caller Base 3.12.

\section{Allele, sequence type, and clonal complex assignment}

The sequencing data were analyzed using nonredundant database (NRDB) comparison tools (https://pubmlst.org/ analysis) to assign alleles. Distinct alleles were identified by comparing the sequences of the same gene, and these were assigned arbitrary numbers. The combination of the seven identified alleles formed the allelic profile, which was used to determine the sequence type (ST), and assigned an arbitrary number. Each observed variation, of at least one allele, generated a new ST $[9,26]$. Clonal complexes (CC) were formed by different STs that shared, at least, three loci with one other member in the group. A clonal complex must include, at least, two STs to be defined as a new clonal group. STs that were not in any CC, were ST singletons [26].

\section{Phylogenetic analysis}

The phylogenetic tree was constructed by Molecular Evolutionary Genetics Analysis 6 (MEGA) using the neighbor-joining method with 1000 bootstraps from the concatenated sequences of housekeeping genes. The sequence was concatenated using UNION, a tool of the European Molecular Biology Open Software Suite (EMBOSS), (http://www.bioinformatics.nl/emboss-explorer/). Then, the sequence was aligned by MAFFT 7 [2].

\section{Isolation of bovine monocytes / macrophages}

Fifty milliliters of peripheral blood was collected from the abdominal vein of a cow in EDTA vacutainer tubes and diluted 1:1 in PBS (pH 7.4) [32]. Then, $10 \mathrm{~mL}$ of blood was added to $3 \mathrm{~mL}$ of Ficoll-Histopaque (density: $10771 \mathrm{~g} / \mathrm{mL}$, Sigma-Aldrich, Brazil), centrifuged at 400 $\mathrm{xg}$ at $4{ }^{\circ} \mathrm{C}$ for $20 \mathrm{~min}$, and the layer of peripheral blood mononuclear cells (PBMC) was removed, washed in PBS $1 \mathrm{X}$ and centrifuged again at $400 \mathrm{xg}$ for $10 \mathrm{~min}$. For monocyte isolation, PBMC was resuspended in solution A ( $5 \mathrm{~mL}$ of RPMI 1640 medium containing 10\% fetal bovine serum) and mixed in $5 \mathrm{~mL}$ solution $\mathrm{B}(5 \mathrm{~mL}$ RPMI 1640 medium $+4.75 \mathrm{~mL}$ Percoll $+0.325 \mathrm{~mL}$ 10X PBS). This suspension was centrifuged at $400 \mathrm{xg}$ for $30 \mathrm{~min}$ at $20^{\circ} \mathrm{C}$ and monocytes were removed between the interface 
of both solutions. To evaluate cell viability, $0.1 \%$ Trypan Blue (viability $>90 \%$ ) was used; the cells were counted in a Neubauer chamber, adjusted concentration $4 \times 10^{5}$ cells / $\mathrm{mL}$ and grown in a $5 \% \mathrm{CO}_{2}$ chamber at $37^{\circ} \mathrm{C}$. After $24 \mathrm{~h}$, the monocytes / macrophages were infected.

\section{Preparation of inoculum and infection of bovine monocytes / macrophages by $U$. diversum}

Six strains (ATCC 49782, BA78, GOTA, S8, 198 and 805), representative of different genetic groups, were grown in UB broth, centrifuged at $300 \mathrm{xg}$ for $30 \mathrm{~min}$, resuspended in PBS and the culture suspension was quantified in 96well microplates to obtain the inoculum based on a Colorimetric Change Unit (CCU). Monocytes / macrophages $\left(4 \times 10^{5}\right.$ cells / mL) were infected with $10^{5}$ ureaplasma / $\mathrm{mL}$ for GOTA, 198, 805 and $10^{4}$ ureaplasma / mL for ATCC 49782, BA78 and S8. Cells treated with LPS representing the positive control and PBS were added to the cells as negative control. After $6 \mathrm{~h}$ of infection, the supernatant was removed, $50 \mu \mathrm{L}$ of trypsin was added to the wells, followed by $50 \mu \mathrm{L}$ of fetal bovine serum. Finally, the

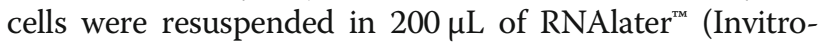
gen, Brazil) and stored at $-80^{\circ} \mathrm{C}$ for later use.

\section{Gene expression}

The mRNA of cells infected with ureaplasma was extracted according to manufacturer's instructions for PicoPure kit (Applied Biosystems, Brazil), with DNAse treatment and RNA elution in a $11 \mu \mathrm{L}$ kit elution solution. The cDNA was obtained by reverse transcription (RT) from the mRNA, using the SuperScript ${ }^{\circ}$ III Reverse Transcriptase kit (Applied Biosystems, Brazil). The cDNA was used in a custom StepOnePlus Real-Time PCR System (Applied Biosystems, Brazil) with SYBR Green (Qiagen-SABioscience, Brazil) to determine the gene expression of TNF- $\alpha$, IL-1 $\beta$, IL-6, IL - 10 and IL17 (Qiagen-SABioscience, Brazil), following the cycle: $50{ }^{\circ} \mathrm{C}$ for $10 \mathrm{~min} ; 95^{\circ} \mathrm{C}$ for $10 \mathrm{~min}$; and 45 cycles of denaturation at $95^{\circ} \mathrm{C}$ for $15 \mathrm{~s}$, annealing at $60^{\circ} \mathrm{C}$ for $1 \mathrm{~min}$. The melting curve was evaluated at the end of the reaction to observe the amplification specificity. The data was analyzed using the $2^{-\Delta \Delta C T}$ [39]. Standardization was performed based on GAPDH expression.

\section{Expression heat map}

The relative expression data of the TNF- $\alpha$, IL-1 $\beta$, IL- 6 , IL-10 and IL-17 cytokines, induced by different strains of $U$. diversum, were analyzed using the heatmapper platform (http: // www. Heatmapper.ca/expression/) and represented as a heatmap. The unsupervised hierarchical grouping was performed using the average distance and the Euclidean distance as metrics.

\section{Statistical analysis}

In this study, three independent experiments were carried out for each of the six strains of $U$. diversum. To compare cytokine gene expression of different strains, the KruskalWallis non-parametric test was used, followed by Dunn's post-hoc test, which makes paired comparisons. All analyses were performed using the GraphPad-Prism 6.0 software (GraphPad software, San Diego, CA-USA). Statistically significant differences were found with $P$ values equal to or less than 0.05 , using IC $95 \%$ for relative expression of cytokines for the different strains.

\section{Supplementary information}

Supplementary information accompanies this paper at https://doi.org/10. 1186/s12917-020-02380-w.

Additional file 1: Figure S1. The strains were isolated from different cattle herds distributed in four states highlighted on the map of Brazil: São Paulo (SP), Mato Grosso do Sul (MT), Minas Gerais (MG) and Bahia (BA) with their respective STs.

\section{Abbreviations}

ATCC: American Type Culture Collection; CC: Clonal complexes; EDTA: Ethylenediamine tetraacetic acid; EMBOSS: European Molecular Biology Open Software Suite; ftsH: ATP-dependent zinc metalloprotease; GAPDH: Glyceraldehyde-3-Phosphate Dehydrogenase; GC: Guanine-cytosine content; hlyA: Hemolysin; IgG: Immunoglobulin G; IL-1: Interleukin-1; IL10: Interleukin-10; IL-17: Interleukin-17; IL-6: Interleukin-6; LAMPS: Lipidassociated membrane proteins; MAFFT 7: Multiple alignment program for amino acid or nucleotide sequences; MBA/mba: Multiple Banded Antigen; mib,mip: MIB-MIP system; MLST: Multilocus sequence typing; NRDB: Nonredundant database; PBS: Phosphate buffered saline; PCR: Polymerase Chain Reaction; PBMC: Peripheral blood mononuclear cells; pld: Phospholipase D; polC: DNA polymerase III; tABC: Ribose transporter; rpL22: Ribosomal Protein L22; RPMI: Roswell Park Memorial Institute; rpoB: RNA polymerase beta-subunit; ST: Sequence types; TNF-a: Tumor Necrosis Factor alpha; tgl: Triacylglycerol lipase; UB: Ureaplasma base; ureA: Urease subunit alpha; valS: Valine-tRNA ligase; VsA: Variable surface antigens; dNTP: Deoxynucleotides.

\section{Acknowledgements \\ Jim Hesson proofread the manuscript (https://www. \\ academicenglishsolutions.com).}

\section{Authors' contributions}

Conceived and designed the experiments: YMFSA, JT and LMM. Multilocus sequence typing: YMFSA, ISR, MSB, ATA, IBSS and LMM. Macrophages isolation and assays: YMSFA, MNSJ, ECQ and BLB. Gene expression: YMFSA, MNSJ, GBC and LMM. Analyzed the data: YMFSA, IBSS, BLB, GBC, JT and LMM Contributed reagents/materials/analysis tools: JT and LMM. Wrote the paper: YMFSA, GBC, JT and LMM. All authors read and approved the final manuscript.

\section{Funding}

This study was supported by National Council for Scientific and Technological Development (CNPq), Brazil (443300/2014-3) and Coordination of Improvement Higher Level Personnel (CAPES -Code 001), Brazil. The funders played no role in the design as well as conclusion of the study.

\section{Availability of data and materials}

The DNA sequences generated and/or analysed during the current study are available in the GenBank repository, Accession: PRJNA632017. The others datasets used and/or analyzed during the current study are available from the corresponding author on reasonable request. 


\section{Ethics approval and consent to participate}

All experiments were executed after approval by the Animal Ethics Committee (AEC) of the Multidisciplinary Health Institute, Federal University of Bahia, under protocol nº 044/2017.

\section{Consent for publication}

Not applicable.

\section{Competing interests}

The authors declare that they have no competing interests.

\section{Author details}

${ }^{1}$ Universidade Estadual de Santa Cruz, Brazil, Jorge Amado Highway, Km 16 , Salobrinho, Ilheus, Bahia 45662-900, Brazil. 'Instituto Gonçalo Muniz, Fundação Oswaldo Cruz, Salvador, Brazil, Waldemar Falcao Street, 121, Candeal, Salvador, Bahia 40296-710, Brazil. ${ }^{3}$ Instituto de Ciências Biomedicas, Universidade de Sao Paulo, Brazil, Professor Lineu Prestes Avenue, 2415, Butantã, São Paulo 05508-900, Brazil. ${ }^{4}$ Instituto Multidisciplinar em Saúde, Universidade Federal da Bahia, Brazil, Hormindo Barros Street, 58, Candeias, Vitória da Conquista, Bahia 45029-094, Brazil.

Received: 19 March 2020 Accepted: 14 May 2020

Published online: 26 May 2020

\section{References}

1. Taylor-Robinson D, Haig DA, Williams MH. Bovine T-strain mycoplasma. Ann N Y Acad Sci. 1967;143:517-8. https://doi.org/10.1111/j.1749-6632.1967. tb27697.x.

2. Marques LM, Rezende IS, Barbosa MS, Guimaraes AMS, Martins HB, Campos $\mathrm{GB}$, et al. Ureaplasma diversum genome provides new insights about the interaction of the surface molecules of this bacterium with the host. PLoS One. 2016;11:1-22. https://doi.org/10.1371/journal.pone.0161926.

3. Dhawan B, Kokkayil P. Ureaplasma: current perspectives. Indian J Med Microbiol. 2015;33:205-14. https://doi.org/10.4103/0255-0857.154850.

4. Amorim AT, Marques LM, Maria A, Gusmão O, Martins HB, Barbosa MS, et al. Apoptosis in HEp-2 cells infected with Ureaplasma diversum. Biol Res. 2014; 47:38. https://doi.org/10.1186/0717-6287-47-38.

5. Buzinhani M, Yamaguti M, Oliveira RC, Cortez BA, Marques LM. Invasion of Ureaplasma diversum in bovine spermatozoids. BMC Res Notes. 2011;4:455. https://doi.org/10.1186/1756-0500-4-455.

6. Razin S, Hayflick L. Highlights of mycoplasma research-an historical perspective. Biologicals. 2010;38:183-90. https://doi.org/10.1016/j.biologicals. 2009.11.008

7. Blum SE, Heller ED, Jacoby S, Krifucks O, Leitner G. Comparison of the immune responses associated with experimental bovine mastitis caused by different strains of Escherichia coli. J Dairy Res. 2017;84:190-7. https://doi. org/10.1017/S0022029917000206.

8. Menghwar H, He C, Zhang H, Zhao G, Zhu X, Khan FA, et al. Genotype distribution of Chinese mycoplasma bovis isolates and their evolutionary relationship to strains from other countries. Microb Pathog. 2017;111:10817. https://doi.org/10.1016/j.micpath.2017.08.029.

9. Zhang J, Kong Y, Feng Y, Huang J, Song T. Development of a multilocus sequence typing scheme for Ureaplasma. Eur J Clin Microbiol Infect Dis. 2014;33(4):537-44. https://doi.org/10.1007/s10096-013-1981-y.

10. Langklotz S, Baumann U, Narberhaus F. Structure and function of the bacterial AAA protease FtsH. Biochim Biophys Acta, Mol Cell Res. 2012;1823: 40-8. https://doi.org/10.1016/j.bbamcr.2011.08.015.

11. Xiao L, Crabb DM, Duffy LB, Paralanov V, Glass Jl, Hamilos DL, et al. Mutations in ribosomal proteins and ribosomal RNA confer macrolide resistance in human Ureaplasma spp. Int J Antimicrob Agents. 2011;37:3779. https://doi.org/10.1016/j.ijantimicag.2010.12.012.

12. Barnes MH, Tarantino PM, Spacciapoli P, Brown NC, Yu H, Dybvig K. DNA polymerase III of mycoplasma pulmonis: isolation and characterization of the enzyme and its structural gene, polC. Mol Microbiol. 1994;13:843-54. https://doi.org/10.1111/j.1365-2958.1994.tb00476.x.

13. Gaurivaud $P$, Laigret F, Bove JM. Insusceptibility of members of the class Mollicutes to rifampin: studies of the Spiroplasma citri RNA polymerase $\beta$ subunit gene. Antimicrob Agents Chemother. 1996:40:858-62. https://doi. org/10.1128/AAC.40.4.858.
14. Razin S, Yogev D, Naot Y. Molecular biology and pathogenicity of mycoplasmas. Microbiol Mol Biol Rev. 1998;62:1094-156. https://doi.org/10. 1128/MMBR.62.4.1094-1156.1998.

15. Ferris $P$, Behbahani N, Neyrolles $O$, Montagnier LUC, Blanchard A. Organization of Ureaplasma urealyticum urease gene cluster and expression in a suppressor strain of Escherichia coli. J Bacteriol. 1996;178:647-55. https://doi.org/10.1128/jb.178.3.647-655.1996.

16. McAuliffe L, Gosney F, Hlusek M, de Garnica ML, Spergser J, Kargl M, et al. Multilocus sequence typing of mycoplasma agalactiae. J Med Microbiol. 2011;60:803-11. https://doi.org/10.1099/jmm.0.028159-0.

17. Becker CAM, Thibault FM, Arcangioli MA, Tardy F. Loss of diversity within mycoplasma bovis isolates collected in France from bovines with respiratory diseases over the last 35years. Infect Genet Evol. 2015;33:118-26. https://doi org/10.1016/j.meegid.2015.04.019.

18. Ruan Z, Yang T, Shi X, Kong Y, Xie X, Zhang J. Clonality and distribution of clinical Ureaplasma isolates recovered from male patients and infertile couples in China. PLoS One. 2017:8:1-12. https://doi.org/10.1371/journal. pone.0183947

19. Tivendale KA, Markham PF, Marenda MS, Browning GF. Genetic diversity of mycoplasma arginini isolates based on multilocus sequence typing. Vet Microbiol. 2015;180(1-2):123-8. https://doi.org/10.1016/j.vetmic.2015.07.028.

20. Brown RJ, Holden MTG, Spiller OB, Chalker J. Development of a multilocus sequence typing scheme for molecular typing of mycoplasma pneumoniae. J Clin Microbiol. 2015;53:3195-203. https://doi.org/10.1128/JCM.01301-15.

21. Tocqueville V, Ferré S, Phuc H, Kempf I, Marois-créhan C. Multilocus sequence typing of mycoplasma hyorhinis strains identified by a real-time TaqMan PCR assay. J Clin Microbiol. 2014;52:1664-71. https://doi.org/10. 1128/JCM.03437-13.

22. Mcauliffe L, Gosney F, Hlusek M, De Garnica ML, Spergser J, Kargl M, et al. Multilocus sequence typing of mycoplasma agalactiae. J Med Microbiol. 2016;60:803-11. https://doi.org/10.1099/jmm.0.028159-0.

23. Overesch $G$, Kuhnert P. Persistence of mycoplasma hyopneumoniae sequence types in spite of a control program for enzootic pneumonia in pigs. Prev Vet Med. 2017;145:67-72. https://doi.org/10.1016/j.prevetmed. 2017.06.007

24. Tatay-Dualde J, Prats-van der Ham M, de la Fe C, Gómez-Martín Á, Paterna A, Corrales JC, et al. Multilocus sequence typing of mycoplasma mycoides subsp. capri to assess its genetic variability in a contagious agalactia endemic area. Vet Microbiol. 2016;191:60-4. https://doi.org/10.1016/j.vetmic. 2016.06.002.

25. Bell-Rogers P, Parker L, Cai HY. Multi-locus sequence types of Mycoplasma bovis isolated from Ontario, Canada in the past three decades have a temporal distribution. J Vet Diagn Investig. 2018;30:130-5. https://doi.org/10. 1177/1040638717731491

26. Rosales RS, Churchward CP, Schnee C, Sachse K, Lysnyansky I, Catania S, et al. Global multilocus sequence typing analysis of mycoplasma bovis. Clin Microbiol. 2015:53:789-94. https://doi.org/10.1128/JCM.01910-14.

27. Kuhnert P. Multilocus sequence typing ( MLST ) of Mycoplasma hyopneumoniae : a diverse pathogen with limited clonality. Vet Microbiol. 2008;127:63-72. https://doi.org/10.1016/j.vetmic.2007.08.010.

28. Königsson $\mathrm{MH}$, Bölske $\mathrm{G}$, Johansson KE. Intraspecific variation in the $16 \mathrm{~S}$ rRNA gene sequences of mycoplasma agalactiae and mycoplasma bovis strains. Vet Microbiol. 2002;85:209-20. https://doi.org/10.1016/S03781135(01)00517-X.

29. Marques LM, Ueno PM, Buzinhani M, Cortez BA, Neto RL, Yamaguti M, et al. Invasion of Ureaplasma diversum in Hep-2 cells. BMC Microbiol. 2010;10:83. https://doi.org/10.1186/1471-2180-10-83.

30. Arfi Y, Minder L, Di Primo C, Le Roy A, Ebel C, Coquet L, et al. MIB - MIP is a mycoplasma system that captures and cleaves immunoglobulin G. Proc Nat Acad Sci U S A. 2016;113(19):5406-11. https://doi.org/10.1073/pnas. 1600546113.

31. Shimizu T. Inflammation-inducing factors of mycoplasma pneumoniae. Front Microbiol. 2016;7:414. https://doi.org/10.3389/fmicb.2016.00414.

32. Gondaira S, Higuchi H, Iwano H, Nakajima K, Kawai K, Hashiguchi S, et al. Cytokine mRNA profiling and the proliferative response of bovine peripheral blood mononuclear cells to mycoplasma bovis. Vet Immunol Immunopathol. 2015;165:45-53. https://doi.org/10.1016/j. vetimm.2015.03.002.

33. Mulongo M, Prysliak T, Scruten E, Napper S, Perez-Casal J. In vitro infection of bovine monocytes with mycoplasma bovis delays apoptosis and suppresses production of gamma interferon and tumor necrosis factor 
alpha but not interleukin-10. Infect Immun. 2014;82:62-71. https:/doi.org/ 10.1128/IAl.00961-13.

34. Jimbo S, Suleman M, Maina T, Prysliak T, Mulongo M, Perez-Casal J. Effect of mycoplasma bovis on bovine neutrophils. Vet Immunol Immunopathol. 2017;188:27-33. https://doi.org/10.1016/j.vetimm.2017.04.011.

35. Roussel P, Cunha P, Porcherie A, Petzl W, Gilbert FB, Riollet C, et al. Investigating the contribution of IL-17A and IL-17F to the host response during Escherichia coli mastitis. Vet Res. 2015;46:1-14. https://doi.org/10. 1186/s13567-015-0201-4.

36. Santos-Junior MN, Rezende IS, Souza CLS, Barbosa MS, Campos GB, Brito LF, et al. Ureaplasma diversum and its membrane-associated lipoproteins activate inflammatory genes through the NF-KB pathway via toll-like receptor 4. Front Microbiol. 2018;9:1538. https://doi.org/10. 3389/fmicb.2018.01538.

37. Yu Y, Chen Y, Wang Y, Li Y, Zhang L, Xin J. TLR2/MyD88/NF-KB signaling pathway regulates IL-1 $\beta$ production in DF-1 cells exposed to mycoplasma gallisepticum LAMPs. Microb Pathog. 2018;117:225-31. https://doi.org/10. 1016/j.micpath.2018.02.037.

38. Sweeney EL, Kallapur SG, Meawad S, Gisslen T, Stephenson S-A, Jobe AH, et al. Ureaplasma species multiple banded antigen (MBA) variation is associated with the severity of inflammation in vivo and in vitro in human placentae. Front Cell Infect Microbiol. 2017;7:1-12. https://doi.org/10.3389/ fcimb.2017.00123.

39. Rao X, Huang X, Zhou Z, Lin X. An improvement of the $2^{\wedge}$ (-delta delta CT) method for quantitative real-time polymerase chain reaction data analysis. Biostat Bioinforma Biomath. 2013;3:71-85. https://doi.org/10.1016/j. biotechadv.2011.08.021.

\section{Publisher's Note}

Springer Nature remains neutral with regard to jurisdictional claims in published maps and institutional affiliations.

Ready to submit your research? Choose BMC and benefit from:

- fast, convenient online submission

- thorough peer review by experienced researchers in your field

- rapid publication on acceptance

- support for research data, including large and complex data types

- gold Open Access which fosters wider collaboration and increased citations

- maximum visibility for your research: over $100 \mathrm{M}$ website views per year

At BMC, research is always in progress.

Learn more biomedcentral.com/submissions 